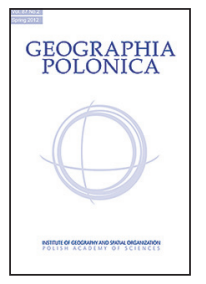 \\ INSTITUTE OF GEOGRAPHY AND SPATIAL ORGANIZATION \\ POLISH ACADEMY OF SCIENCES \\ www.igipz.pan.pl

\title{
THE LOCAL BORDER TRAFFIC ZONE EXPERIMENT AS AN INSTRUMENT OF CROSS-BORDER INTEGRATION: THE CASE OF POLISH-RUSSIAN BORDERLAND
}

\author{
Iwona Sagan ${ }^{1}$ • Vladimir Kolosov ${ }^{2}$ Dominika Studzińska ${ }^{1}$ \\ Maria Zotova $^{2}$ - Alexander Sebentsov ${ }^{2}$ - Klaudia Nowicka ${ }^{1}$ \\ ${ }^{1}$ Department of Economic Geography, Faculty of Oceanography and Geography \\ University of Gdańsk \\ Bażyńskiego 4, 80-309 Gdańsk: Poland \\ e-mails: geois@univ.gda.pl・geods@univ.gda.pl•geokn@univ.gda.pl \\ ${ }^{2}$ Institute of Geography \\ Russian Academy of Sciences \\ Staromonetny pereulok 29, 119017 Moscow: Russia \\ e-mails: vladimirkolossov@gmail.com・zotovam@bk.ru・asebentsov@gmail.com
}

\begin{abstract}
The main objective of this article is to offer an answer to the question whether introducing local border traffic (LBT) on the external frontiers of the EU is an effective tool for cross-border integration and development of marginalised border areas. The analysis was carried out in an area of particular strategic importance for the European Community and Russia, which is the Polish-Russian borderland. The study includes the analysis of political discourse supplied with the findings from the original survey revealing mutual perception of Polish and Russian partners. The authors drew special attention to the significance of delimitation of areas included in the visa-free traffic. The success of the four-year period of LBT zone's functioning on the Polish-Kaliningrad border came as a result of modification of the regulations concerning the scope of the zone and the inclusion of economic regions otherwise heavily affected by the split in the functional dimension. The analysed region had the chance to become a model of national and local policies' cooperation in border areas. The decision to shut down the LBT has proved yet again that socio-economic initiatives in border regions are deterministically dependent on the decisions of central governments.
\end{abstract}

\section{Key words}

local border traffic $\bullet$ cross-border integration $\bullet$ Polish-Russian border $\bullet$ external border of the European Union 


\section{Introduction}

Historical variability of Polish-Russian crossborder cooperation provoked subsequent phases of emergence and disappearance of alienated or co-existing borderland. The creation of local border traffic (LBT) zone in 2012, which connected the Kaliningrad Oblast and two Polish regions - Pomeranian and Warmian-Mazurian - by means of visa-free traffic, initiated, for the first time, a third-degree integration process, i.e. formation of an interdependent borderland. The dynamic and highly successful experiment of integration of the regions on both sides of the boundary was interrupted in 2016 with the decision of Polish government to shut down the zone.

Intense cross-border traffic in the LBT zone initiated the process of creating a crossborder soft space (Allmendinger et al. 2015), i.e. a space integrated by grass-root activity of its residents and economic entities, which is simultaneously regulated by different, statutory planning, economic and social policies. This type of spaces emerges as a result of direct physical proximity of areas that belong to different administrations or governances, be it local, regional, or national. As such, they are socially produced specific spaces, independent from political and territorial divisions. Soft spaces are functional regions that do not necessarily correspond to the existing functional links. Their development is conditioned by different administrative systems existing within them. The formation of soft spaces anticipates establishing of functional links resulting from new directions of development that are expected to emerge from the new situation and/or initiated changes. The abolition of the visa regime, along with some new opportunities for activity it had introduced in the LBT zones, doubtlessly gives a strong impulse for formation of such areas. However to set off the mechanism that forms a soft area it is necessary to delimit a LBT zone so that it covers the potential of social and economic links that exist on both sides of the frontier. Strict adherence to the arbitrarily defined range of the zone $-30 \mathrm{~km}$ or $50 \mathrm{~km}$ from the border - contradicts the idea of the policy, in which the LBT zone is a tool for crossregional integration.

The policy of cross-border integration has moved on from the premise of a LBT zone as an instrument for compensating social contacts of homogeneous groups that were divided by state borders, yet only in such aspect could the very limited range of the zone of visa-free traffic find justification. Integration has become the prime objective of the good neighbourhood policy, rather than simple social reintegration of border regions. Nevertheless, the new interpretation of the function of the LBT zones was not followed up with any modifications in the laws that shape the legal framework for their creation. Expanding substantially the range of the LBT zone around the Polish-Kaliningrad Oblast border constituted an exceptional departure from the regulations governing the establishment of such zones.

The Polish-Kaliningrad region of Russia border is the border of rather peripheral localization to the main communication corridors and the border being mainly crossed by local inhabitants. However, it is of global significance. Glocality of the local border traffic zone is reflected in the utilization of its international and global meaning for achieving the local interests. An attempt to interpret the highly complicated, dynamic and fragile cross-border interactions as well as regional policy between Poland and Kaliningrad Oblast is taken in this paper.

The authors pay attention to the impact of asymmetric and asynchronic developments on the formation of cross-border functional region between Kaliningrad and the Polish agglomeration of Three Cities - Gdansk, Gdynia and Sopot. The introduction of the local border traffic (LBT) regime changed the lifestyle in the borderland. For Kaliningrad citizens it opened a much easier access to Europe. The loosed border regime reduced functional distance between Poland and Kaliningrad and in a broader sense, between the European Union and Kaliningrad. Although in many cases the crossborder cooperation programmes are realized independently on each side of the border 
which turns them rather into the near then the cross border activity. The problem of the asymmetry in the programmes realisation is well analyzed in scientific literature (Melnik 2006; Tanaka 2006; Sebentsov \& Zotova 2013). Among the main explanations of the situation are: the institutional inequality between partners, insufficient level of civil society development, the lack of specialists able to compile and to manage international projects.

On the base of the analysis it can be stated that the border started to be perceived as a resource in local economy after the LBT introduction. A number of border localities gained a chance for development. Gdansk, which had been included into the LBT zone, became a new border town. Benefits of an early stage of the border regime loosening were obvious for both regions. Nevertheless, the cross border interactions cannot be fully justified, at the stage they reached, as integration of two neighbouring sides into, the unavoidably specific, but actually one border region. The abrupt end of the cooperation has proved the fragility of elaborated agreements.

\section{The objective and the methodology of the research}

The main objective of this article is to offer an answer to the question whether introducing local border traffic on the external frontiers of the EU is an effective tool for cross-border integration and development of marginalised border areas. The article presents how the Polish-Russian borderland was functioning after the local border traffic agreement had entered into force. The conducted analysis indicates that local border traffic is a tool that the European Union and/or state authorities fail to take advantage of, and which introduction would introduce a series of benefits exceeding the basic premises of the EU regulations.

To assess the impact of the LBT zone, and to gather opinions regarding the subject, the authors carried out a number of interviews and surveys on both sides of the Polish-Russian border. During the study, 45 expert interviews were conducted in Polish border area included in the local border traffic agreement, which allowed to evaluate the effects of introducing visa-free traffic in the studied borderland. Interviewees included representatives of local authorities, NGOs, and entrepreneurs. In 2013 a survey was carried out among the residents of Polish border zone and 250 questionnaires were collected. Also, a survey was conducted among citizens of Kaliningrad Oblast who visited Tri-City. Its purpose was to gather opinions of Russians on tourist attractiveness of Tri-City agglomeration. The survey took place in November and December 2013 on a border crossing point connecting Tri-City with Kaliningrad, obtaining a $n=462$ sample. Additionally, a survey was carried out among the residents of Tri-City $(n=402)$. This allowed to evaluate local border traffic from the perspectives of all the citizens impacted by the LBT agreement, both from major urban centres and those from smaller border towns. The information was complemented with the data from Russian and Polish Central Statistical Offices, Russian Regional Customs, Border Guard, and Customs Chamber.

\section{Local border traffic on the external borders of the European Union}

Visa-free agreements, having a long historical tradition, are bilateral agreements increasing permeability of borders and making lives of borderland inhabitants much easier. Such agreements that were concluded soon after the First World War concerned subsequent boundaries and solved the problem of commuters - mainly people who owned arable land on the other side of a border (for instance, such agreements were concluded between Hungary and Yugoslavia, Poland and Czechoslovakia, Norway and Finland). In the 1990s there were three local border traffic agreements concluded between Poland and: Germany (entered into force in 1993), the Czech Republic (1995) and Slovakia (1997). They introduced passport-free traffic and people who took part in it were inhabitants of border regions, registered tourists and, in the case of Germany, almost all citizens 
(Komornicki 1999). According to Komornicki (1999), this 1990s local border traffic was the first step to future introduction of passportfree traffic like the one existing in the European Union at present.

The enlargement of the European Community complicated the relations and contacts of the states separated by the external frontier of the EU. To prevent further isolation, the European Parliament and Council issued a regulation (No.1931/2006) laying down provisions for local border traffic on the external frontiers of Member States. Rules referring directly to visa-free traffic in border areas were included in the Regulation of the European Parliament and Council No. 1931/2006 of the 20th December 2006.

Local border traffic is defined by the EU as regular crossings of the external land border of the European Community by residents of border areas with the intention of staying within the border area of the neighbouring country for social, cultural, family, or justified economic reasons (excluding commercial activities) for a period not exceeding 3 months ${ }^{1}$. A border area is defined as an area located not further than 30 kilometres from the frontier (50 km in exceptional cases). The residents, living in the areas included into the visa-free traffic area for not less than 1, year may freely cross the border and are exempted from the visa obligation (Regulation No. 1931/2006). Since the Regulation's entry into force, seven local border traffic agreements were signed (Tab. 1). Two visa-free traffic agreements were introduced on Polish borders. The agreement between Poland and Ukraine was signed on the 1st of July 2009, while the agreement with Russia was signed on the 27th of July 2012. Local border traffic is deemed to be the most effective instrument of visa liberalisation, which boosts the dynamics of traffic with only minor negative effects (Jaroszewicz 2012). Additionally, it is considered to be an important impulse for the development of border areas.

Thanks to numerous facilitations, the visafree traffic contributes to more frequent and regular crossings of the border. Additionally, introducing special border crossing points and traffic lanes increased the infrastructural permeability of the boundary. Based on the Second report on the implementation and functioning of the LBT regime, presented by the European Commission to the Parliament and the European Council, a conclusion was drawn that the LBT permits were highly popular among the residents of border areas. The information gathered by the European Commission for the purpose of the Second report... indicates that the holders of the LBT cards cross the borders regularly. This confirms the positive impact of the LBT on cross-border exchange and cooperation, as well as on relations between the residents of the borderland.

Table 1. Visa-free traffic agreements on the external borders of the European Union

\begin{tabular}{|c|l|c|}
\hline No. & \multicolumn{1}{|c|}{ Countries } & Day of the entry into force \\
\hline 1 & Hungary - Ukraine & January 2008 \\
2 & Slovakia - Ukraine & September 2008 \\
3 & Poland - Ukraine & July 2009 \\
4 & Romania - Moldova & October 2010 \\
5 & Belarus - Latvia & February 2012 \\
6 & Norway - Russian Federation & May 2012 \\
7 & Poland - Russian Federation & July 2012 \\
\hline
\end{tabular}

Source: Based on Jaroszewicz (2012) and Umowy ... (2012).

\footnotetext{
1 Total duration of stay cannot exceed 90 days within a six months' period, counted from the day of first entry.
} 
The provisions regarding the local border traffic can significantly facilitate the life of citizens of the EU living in the vicinity of Community's external borders. Visa-free traffic agreement is an important instrument that mitigates the impact of visa regime and increases crossborder traffic (Doliwa-Klepacka 2011). A detailed analysis of introduction and functioning of local border traffic on the Polish-Russian border offers an opportunity to better understand LBT's influence on the functioning of the frontier, on the inhabitants of the border areas, and on the nature of neighbourly relations.

\section{The transformation of the Polish-Russian border}

The process of re-bordering between Russia and Poland can be divided into two stages. In 1945-1989, the USSR and Poland delimited and demarcated a new Soviet-Polish border established by the treaty of 16 August 1945 (Eberhardt 2012). Later, in 1985, the sides signed the agreement on maritime boundaries. Though before 1989 Poland was an ally of the Soviet Union, the boundary between them was closed for free circulation.

The collapse of the Soviet Union has radically changed the geopolitical situation of Kaliningrad. The region has become an exclave of Russian Federation separated from its main territory by Lithuania and Belarus. When Lithuania and Poland became member states of the EU and NATO, the situation has become even more complicated. The problems typical for all exclaves and related with international transit, economic competitiveness, etc have become more disruptive.
During the first years after the disintegration of the Soviet Union two opposite processes were going on: re-bordering on the LithuanianRussian border, which used to be a transparent boundary between two Soviet republics, and de-bordering at the Russian-Polish border, which was being opened. At the regional level, they were actively establishing legal and institutional infrastructure and developing practice of cross-border cooperation (Palmowski 2010; Rožkov-Jur'evskij 2014).

The growth of permeability of the border was related to i.a. development of infrastructure comprising currently seven border crossings, which include four road crossings (Grzechotki-Mamonovo II, Gronowo-Mamonovo, Bezledy-Bagrationovsk, Gołdap-Gusev) and three railway crossing points (Braniewo-Mamonovo, Głomno-Bagrationovsk, SkandawaZheleznodorozhny). For the last time, the infrastructure was extended in 2010, when the Grzechotki-Mamonovo II crossing point opened, connecting Tri-City with Kaliningrad. Since 2010 the mean distance between border crossing points is ca. $33 \mathrm{~km}$ (Tab. 2), which according to Moraczewska (2008), is a sufficient density, given the short length of the border and its 'regional' nature (i.e. majority of the crossing points is used by local and regional traffic).

In 1991-2003, inhabitants of Kaliningrad profited of visa-free regime with neighbouring countries (Komornicki 2010). Since 2000, representatives of the region have been involved in the dialogue between Russia and the EU concerning the regime. Negotiations about mainland Russia's communications with its exclave were particularly difficult.

Table 2. Development of the number of crossing points on the Polish-Russian border in the years 19932015

\begin{tabular}{|c|c|c|c|}
\hline $\begin{array}{c}\text { Total length } \\
\text { of the border }(\mathrm{km})\end{array}$ & \multicolumn{2}{|c|}{$\begin{array}{c}\text { Total number } \\
\text { of crossing points }\end{array}$} & $\begin{array}{c}\text { Average distance } \\
\text { between crossing points }\end{array}$ \\
\hline 232 & 1993 & 4 & 58 \\
1995 & 6 & 38.66 \\
& 2010 & 7 & 33.14 \\
\hline
\end{tabular}

Source: Based on Moraczewska (2008), Palmowski (2013). 
The European side consecutively declined all Russian proposals and refused to take into account any Russia's arguments about the specific situation of the region and to conclude special agreements. Leaders of the European Commission referred to the inviolability and versatility standards established by the Schengen Agreement, and strong support for the national sovereignty of Poland and Lithuania, which excludes any possibility of the adoption of the Russian proposals for the transit through their territory. Since July 2003 Lithuania and since October 2003 Poland have begun to apply the Schengen regime in communication with Russia. Poland tried to postpone this date as late as possible. For travelling to Poland and Lithuania between 2003 and 2007 they had to have an international passport and a visa, but the visa regime was simplified, and it was possible to get a multientry visa valid for a year without invitation and for free (Anisiewicz \& Palmowski 2014). In 2003 the Lithuanian authorities introduced a special transit document (it means that tickets must be purchased more than 24 hours before the departure) for passengers travelling by train to Russia and back. Since 2005 the transit passengers also need to have an international passport. Moreover, some issues regarding transit via Lithuania still wait for decisions. In 2007 Polish authorities adopted the Schengen norms and requested from Russian citizens a visa issued only on the basis of the invitation letter.

The long-awaited Russia-EU agreement on the facilitation of the visa regime, which came into effect on June 1, 2007, resulted in a stricter visa regime for the residents of the region. Instead of a free one-year visa for travel to Poland and Lithuania, the residents had to obtain a one-entry visa paying a 35-euro fee. A tighter visa regime and the application of common EU rules to the traffic of physical persons across the eastern EU borders provoked its decrease and gave rise to difficulties for a part of local population, which lived on small cross-border trade (Palmowski 2010).

Before Poland's accession to the Schengen area, 2,500 to 5,000 persons passed
Gronowo-Mamonovo crossing point daily. In 2008 their number dropped to 1,500-2,000. The total traffic decreased from almost 3 million in 2007 to less than 1.3 million in 2009 (Fig. 1). So, integration of Poland and Lithuania to the EU led to new customs and border barriers for both ordinary people and economic actors.

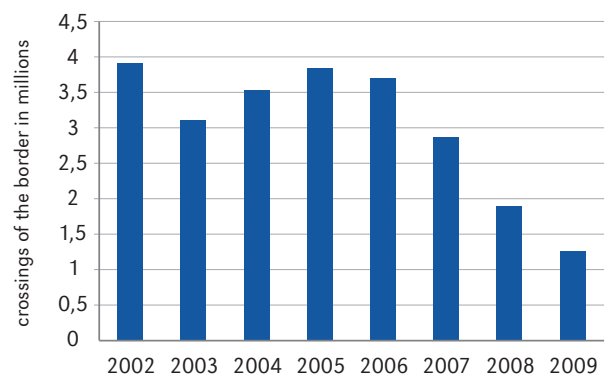

Figure 1. Number of crossings of Polish-Russian border in the years 2002-2009

Source: Based on Border Guard (Straż Graniczna) statistics, 2016.

Since the very beginning the discourse about the exclave was devoted to the contradiction between the need to establish common legal norms for all Russian territories and for the EU countries, on the one hand, and the need to take into account uniqueness of the Kaliningrad case, on the other. In order to compensate such high economic and social costs of transit, Kaliningrad regional authorities tried to obtain additional funds, privileges and especially a special status. The proposals varied from the establishment of a free economic zone to a broad autonomy from the federal centre with a further full or partial integration to the EU. Radical voices were rather marginal but they did not contribute to a favourable attitude of Moscow to claims of a special customs' and fiscal regime. Fears to lose control over Kaliningrad and apprehensions of a total restructuring of the Baltic region's geopolitical map prevailed.

On its side, the EU refused to consider Russian arguments about a specific situation of the exclave. The visa regime was in general the main theme of the debate on Kaliningrad. 
The gradual tightening of the border regime was perceived as the main obstacle to crossborder cooperation and integration of the region into the European space. A constant motive was to blame the EU in applying double standards: simplifying or even abolishing visas for many countries the EU declined Russian requests of the visa free regime. Sometimes the obstinacy of Brussels was opposed to the interest of Polish and Lithuanian border regions in better communication with Kaliningrad.

At the same time, great attention was paid to searching for compromise solutions in bilateral relations between Russia and the EU. Thanks to a number of research projects supported by the EU and carried out jointly by experts from Russia and European countries at the beginning of the 2000s, the idea to transform Kaliningrad region into a 'pilot region' of economic cooperation between Russia and the united Europe was largely discussed. The discussion coincided with the creation of euroregions, the simplification of the visa regime ${ }^{2}$, the development of cross-border and inter-regional contacts in various fields and of multilateral cooperation within the entire Baltic region.

Despite of controversial voices, a general conclusion was that an optimal strategy would be in reaching a balance between the tasks of keeping Kaliningrad within the economic, legal, cultural and political space of Russian Federation and the region's openness. Moreover, one is impossible without another (Fedorov 2010; Fedorov et al. 2013). The Concept of the Federal Socio-Economic Policy Toward Kaliningrad Region adopted in 2001 stated that "The main objective to realize national interests and security in Kaliningrad region is the creation of the economic, international, political and military-strategic conditions which would exclude the weakening of its role and importance as an integral part of Russian Federation". Then the authors of the document declare that these conditions comprise stable

\footnotetext{
2 Since 2010, Polish authorities simplified the access of Russians citizens to Polish neighboring regions in issuing more long-term multi-entry visas.
}

socio-economic development of the region, the increasing of its population's level of life which should be comparable with the neighbouring EU countries. The implementation of this task is impossible without an active participation in the processes of economic regionalization on the Baltic.

\section{The local border traffic in the Polish-Russian borderland}

Polish and Lithuanian governments have begun to discuss the possibility of the simplification of the visa regime with Kaliningrad region (Anisiewicz \& Palmowski 2014). But the observation of common technical requirements could divide population of Kaliningrad region into three categories: those who can visit either Poland or Lithuania (in the framework of LBT) or none of these countries. Residents living in the municipalities situated beyond the 30-50 kilometres range from the border, that is established by the regulations, couldn't use this procedure.

In April 2010 Russia's and Poland's Ministers of Foreign Affairs S. Lavrov and R. Sikorski suggested the European Commission extending special conditions of cross-border travels to all residents of Kaliningrad region (Anisiewicz \& Palmowski 2014). Radosław Sikorski stated: "We will do everything to persuade the EU to change the instructions. If that fails, then we are prepared to take the risk of reaching such agreement even if some people in Brussels don't like it. Poland and Russia showed Europe our joint position" (Visa privileges... 2010).

The European Commission agreed to make an exception: the LBT area was delimited not within the distance of 30 or $50 \mathrm{~km}$ from the boundary but the entire Kaliningrad region and parts of two voivodeships in Poland, Warmińsko-Mazurskie ${ }^{3}$ and Pomorskie ${ }^{4}$ were

\footnotetext{
3 Including the cities of Elblag and Olsztyn and the counties of Elbląski, Braniewski, Lidzbarski, Bartoszycki, Olsztyński, Kętrzyński, Mrągowski, Węgorzewski, Giżycki, Gołdapski, and Olecki.

${ }^{4}$ Including Gdańsk, Gdynia and Sopot and the counties of Gdański, Nowodworski and Malborski.
} 
included (Fig. 2). This solution was considered as a noticeable achievement of the Polish and Russian politicians. The population of the area covered by the LBT regime makes up about 2.8 million people in all, including 941,500 Russian and 1,900,000 Polish citizens. The agreement between two countries was signed on December 14, 2011 and came into force on July 27, 2012.

Unlike Poland, Lithuania was not prepared to extend the LBT regime to the whole Kaliningrad region. Lithuanian politicians appealed to the regulations of the EU and were afraid of failing safety requirements, smuggling, and damage to the local economy (Lithuanian Foreign Minister... 2010). As a result, the agreement with Lithuania was not signed, though residents of Lithuanian border regions, especially businesspersons and other local stakeholders supported the establishment of the LBT regime (Lithuania has frozen talks... 2014).

In accordance with the 2012 agreement between the Republic of Poland and the Russian Federation, local border traffic on PolishRussian border made multiple crossing of the frontier possible for residents of the zone, who lived in the area covered by the agreement for not less than 3 years. The inhabitants of the Polish-Russian borderland could freely cross the border initially holding 2 year, and later 5 years permits for visa-free traffic, for a fee lower than that of a Schengen visa, i.e. costing EUR 20.

Signing the agreement on the local border traffic was one of the more significant events in recent history of EU-Russian and PolishRussian relations. The introduction of a visafree zone on Polish-Russian border was a sui generis experiment of modifying the visa regime in regards to the Russian Federation. Agreement's entry into force not only brought numerous benefits to the residents, entrepreneurs, as well as local and regional authorities of the borderland, but also changed the relations on national and transnational levels. The introduction of visa-free traffic and more frequent neighbourly contacts stimulated cross-border cooperation of the countries. The conclusion of the agreement constituted another step in the EU-Russian relations. The pilot nature of Kaliningrad Oblast, in the context of the EU-Russian relations, converted

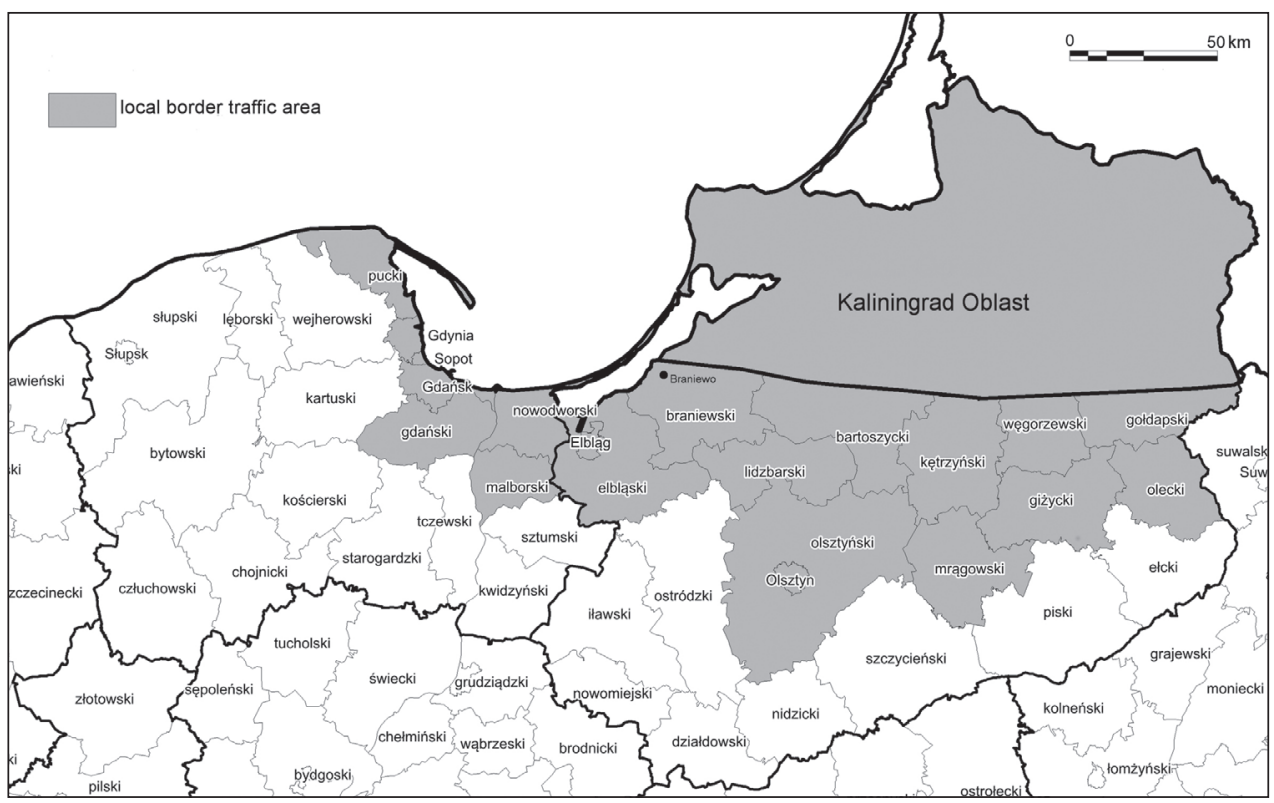

Figure 2. The local border traffic zone at the Polish-Russian borderland Source: Domaniewski and Studzińska (2016). 
the Polish-Russian borderland into an international affair, thus making this region a very interesting research area.

On the 1st of July 2016 Polish Ministry of Foreign Affairs shut down the local border traffic with Kaliningrad Oblast and Ukraine, on the grounds of security concerns related to the NATO summit and the World Youth Days organised in Poland at that time. In response to this decision on the 2 nd of July the Russian authorities also suspended the agreement on visa-free traffic. Ukraine did not take similar steps. After the international events in Poland had ended, the LBT on the Ukrainian border was re-established. However, it was still suspended on the Russian border. The official communication of Polish authorities informed that concerns related to the safety of the border were still justified. In spite of protests and efforts of some Polish regional leaders from the LBT area, the traffic has not been re-established until today.

\section{The effect of introduction of local border traffic on the Polish-Russian border}

The LBT created an opportunity for developing a new form of cooperation between the neighbouring regions. First of all, it increased permeability of the border. According to the data collected by the Polish Border Guards (2016), about 50\% of Kaliningraders come to Poland in years 2013-2014 using the LBT cards (Fig. 3). From July 2012 to July 2014, the consulate of Poland in Kaliningrad issued more than 200 thousand cards. The data of the Russian regional customs shows that the number of persons and cars crossing the Polish border increased by the ratio of 4 in 2013 as compared with 2010 and even exceeded the flow during the visa free period. In 2013, 6 million crossings were registered (Fig. 4).

The introduction of local border traffic, which resulted in mass daily crossings, changed the permeability of the border in the infrastructural dimension. Increased traffic forced modifications of border infrastructure. The permeability of the Polish-Russian

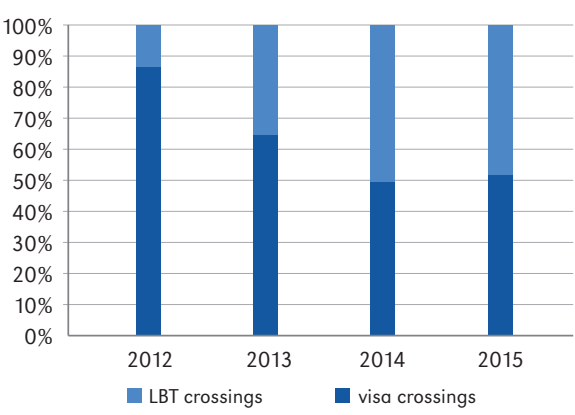

Figure 3. The number of Russians crossing the Polish-Russian border within the local border traffic and visa-free regimes in the years 2012-2015 Source: Based on Border Guard (Straż Graniczna) statistics, 2016.

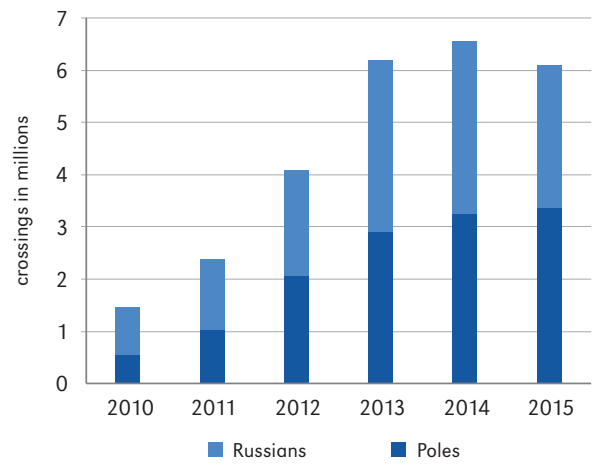

Figure 4. The number of crossings of Polish-Russian border in the years 2012-2015.

Source: Based on Border Guard (Straż Graniczna) statistics, 2016.

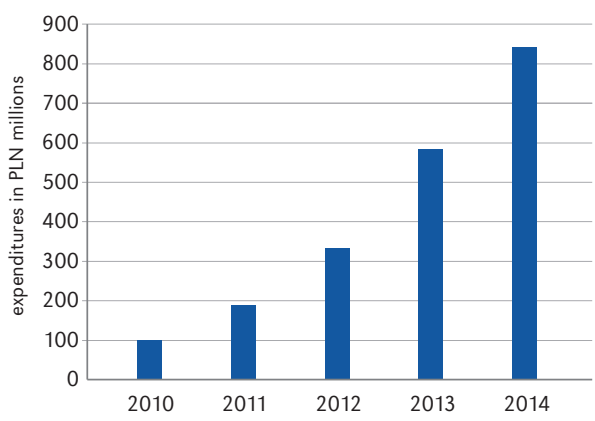

Figure 5. Russians' expenditures in Poland in the years 2010-2014

Source: Based on Border Guard (Straż Graniczna) statistics, 2011-2015. 
border was improved through e.g.: introduction of special traffic lanes for people crossing the border within the LBT regime, automated printing of migration cards for people entering Kaliningrad Oblast, digital notifications on arrival of organised groups at road crossing points (e-booking) (Dudzińska, Dyner 2013).

Though the formal reason for obtaining the LBT card were cross-border family ties, as well as different social, cultural, and economic connections, it was evident that the main beneficiaries of the LBT were cross-border traders. Kaliningraders were buying food and toiletry while Poles were crossing the border to buy fuel. According to the Central Statistical Office's data in 2013 92.1\% of Poles crossed the border for shopping purposes, thus increasing greatly the expenditures of Polish citizens in Kaliningrad Oblast. In 2012 Poles' expenditures in the exclave grew by $147 \%$ compared to previous year. Furthermore, in 2013 the value of expenditures grew by $232 \%$ compared to previous year. According to the Polish experts' assessments, about 75\% of Poles entering the region of Kaliningrad as participants of the LBT, went only to the nearest petrol station and spent in Russia no more than one or two hours. In 2012, Polish 'tanker' traders brought 160M litres of fuel from Russia. Mass purchases of fuel in Russia have contributed to the decrease of number of petrol stations in Polish border area. Data provided by the Polish Statistical Office indicate that in 2012 there were 340 stations in WarmińskoMazurskie Voivodeship. In 2014 this figure dropped to 266.

All in all, ordinary citizens going shopping at weekends and holidays, and spending free time gradually substituted 'shuttle' traders. A relatively high per capita private car ownership rate in Kaliningrad (330 autos per thousand inhabitants) makes it possible to visit Polish border regions very often. The lowest food prices across the European Union (61\% of the EU average) and a high quality of Polish goods attracted Russians (The lowest food prices... 2015). In 2012, the average cost of the consumer basket in Gdansk was approximately $20-23 \%$ less than in Kaliningrad. The reason for such a situation is the exclave status and the cost of transit to Kaliningrad, as well as the institutional structure of retail trade.

According to the Central Statistical Office, $59.1 \%$ of Russians crossing the border in 2013 visited Poland to do shopping while $16 \%$ came as tourists. The Office's statistics revealed also that in 2013 the Russians spent PLN 583.9M, mainly within the area covered by the local border traffic. According to the Polish customs' data, in 2014 only the residents of Kaliningrad region spent in shops, restaurants and hotels in Poland at least 10-11 billion rubles (44\% more than in 2013). What is more, the payment documents submitted for tax-free collection showed that during the first six months of 2014 they bought goods and services in Poland for about 92 million zloty, or 22 million euro. It is nearly two times more than for the same period of 2013. Clearly, the real sum is much higher (Russian West 2014). Characteristically, shopping is yielding its positions to other types of tourism: healthcare, entertainment, visit of different events, etc.

The presented data confirm a positive and stimulating impact of the LBT on local economies on both sides of the border. The difference in availability of products and goods combined with ease of crossing boosted the economic development of an otherwise marginalised borderland. As the number of crossings grew, new retail and service facilities, dedicated to the clients from abroad were opening. A Biedronka discount store built in the immediate vicinity of the crossing point in Gołdap or shopping centres in Braniewo and Bartoszyce serve as examples. The study by Central Statistical Office confirms that in 2015, in the areas of Warmińsko-Mazurskie Voivodeship covered by the LBT agreement, there were more stores operating then before the introduction of the visa-free agreement (Fig. 6). The growth was particularly dynamic in the Warmińsko-Mazurskie Voivodeship's counties (powiat) with a lower saturation of commercial network.

The counter-sanctions against the EU and other Western countries adopted by Russia as a reaction to the measures taken as a result 


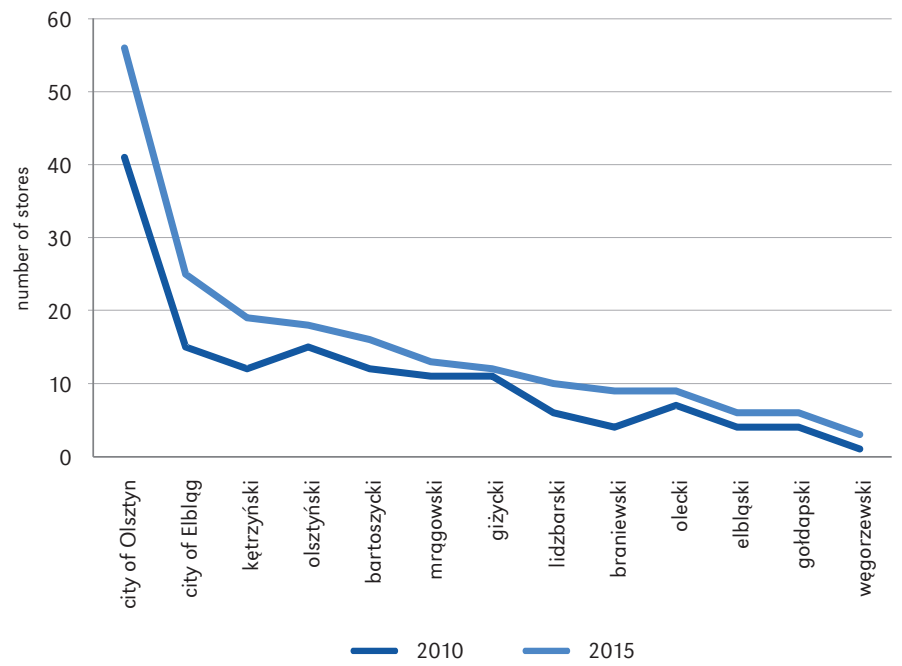

Figure 6. Stores in counties of the Warmińsko-Mazurskie Voivodeship covered by the local border traffic agreement in the years 2010-2015

Source: Based on BDL (Local Data Bank), 2016.

of the Ukrainian crisis and the ban of foodstuff import led first to the increase of the ' $g r e y$ ' import by Russian individual tourists from Poland to Kaliningrad. Before the embargo the region was $70 \%$ dependent on imports of dairy products, 50\% - on the supply of fruit and vegetables and $40 \%$ - on imports of poultry meat from the EU. Soon after the introduction of counter-sanctions, prices of some products have increased by 1.5-2 times. Cross-border shuttle traders have firstly benefited from these decisions: they can bring up to $5 \mathrm{~kg}$ of products that fall under counter-sanctions for private consumption. These goods were accumulated by large commercial structures. Such shuttle trade and smuggling helped to soften the situation in the retail markets of the Kaliningrad region (Russia after the embargo... 2015).

However, after a sharp ruble depreciation in October 2014, shuttle trade from the EU ceased to be profitable. As a result, in January 2015 border crossings felt down by $41 \%$ as compared with the same period of the previous year. At the same time, the number of shop-tourists from the Baltic States and Poland who were actively buying cheaper Russian goods intensively increased. On the first weeks after the depreciation Poles were actively buying on the Russian side not only foodstuff, but also electronics (Russian food 2015). Polish Ministry of Agriculture estimated the rise of Russian foodstuff's export to Poland in 2014 in 78.9\% as compared with 2013 (in monetary terms, it reached 160.6 million euros).

With the stabilization of ruble in spring 2015, the intensity of trips began slowly recovering. Residents of Kaliningrad started to visit neighbouring Polish towns again for shopping and spending their free time. Individual shopping and one-day recreational trips without lodging became more popular. According to the Customs Chamber in Olsztyn in the first five months of 2016 the number of crossings fell by only $8 \%$ as compared with the same period of 2014. From month to month of the first half of 2016 the number of Russians visiting Poland was increasing. According to some experts, Russians did not stop buying goods in Poland thanks to their very positive opinion about Polish products (Polska wciąż... 2015).

The LBT regime was established in some other areas of the eastern EU borders (Latvia - Russia, Belarus - Latvia, Hungary - Ukraine, Slovakia - Ukraine, etc.) but nowhere such 
spectacular results were achieved. The key to a success was the inclusion of large cities (Kaliningrad, Gdansk, Sopot, Gdynia and Olsztyn) that provide a high level of services. The difference in prices belonged to the driving force of everyday cross-border interactions. Ordinary citizens benefited from the establishment of the LBT, which gave them access to cheaper goods. The LBT undoubtedly gave the opportunity to build closer neighbour relationships. It has have a strong impact on entrepreneurs, businessmen, journalists, intellectuals, and officials from Kaliningrad, as well as those from Tri-City and Olsztyn. The people have become interested in domestic issues and life in Poland. This has created a common information space and interest in each other, has increased trust and communication between neighbours.

Direct contacts allowed to confront mutual stereotypes and prejudices with the reality. The local experts suggested that the LBT regime could have created a common trans-border space. They believed that despite of the significant worsening of Russian-Polish relations, residents of neighbouring areas would have kept their contacts and continued to feel comfortable on both sides of the border. For many residents of Kaliningrad Oblast the Polish neighbouring regions represent the EU territory that is treated as a reference point. They live in Russian Federation, in the Russian economic and legal space, but also partly in another dimension. It is a source of a new Kaliningrad identity. This borderland may be perceived as a kind of a laboratory where future models and forms of interstate cooperation might be tested and implemented.

For Russia as a whole Poland seems to be one of the least friendly countries (Russian-Polish relations 2015). According to recent polls of the Levada Centre, in the eyes of Russian citizens Poles run the 5th in the list of peoples who are hostile to Russia following Ukrainians, Georgians, Americans and British. But the attitude of Kaliningraders to Poles and Poland has not changed since the establishment of the EU sanctions against Russia. $60 \%$ of the region's inhabitants are neutral or positive to Poles (Attitude of Kaliningraders... 2014). Survey of the All-Russian Public Opinion Research Centre (VTsIOM) showed that $51 \%$ of Kaliningraders perceive RussianPolish relations positively (Report 2015). At the same time, according to the survey of the Centre for Polish-Russian Dialogue and Understanding $55 \%$ of Polish citizens polled in the area covered by the LBT regime have positive emotions associated with Russians ${ }^{5}$. The vast majority of Polish participants of the survey conducted by the authors in the counties covered by visa-free traffic considered the relations with Kaliningrad Oblast good (48.8\%) and $19.2 \%$ thought they were very good. Slightly more than $30 \%$ of Polish interviewees perceived neighbourly relations with Russia as neutral. Only $1.6 \%$ described the relations as bad.

The inhabitants of the borderland meet in stores and restaurants but do not interact; they function 'in parallel to each other' (Wenerski \& Kaźmierkiewicz 2013). Place of residence and work, the frequency of contact with the Russians, education, and age impact the perceptions of the neighbours. Historical relations of Poles and Russians impede full integration, however more frequent contacts reduce tensions between the inhabitants of the borderland and diminish the impact of media and national government on daily neighbourly relations. A taxi driver from Gdansk declared in an interview to polish sociologists: "Between Poles and Russians, there are no discords. Conflicts are at a higher level". An employee of the Museum of Amber in Gdansk seconded him: "I often meet Russians, they are open, nice, not noisy, and they have the same temperament as Poles. I perceive them well". A survey conducted by the authors among the residents of Tri-City seems to confirm the statements presented above. Over $81 \%$ of respondents from Tri-City declared they did not mind the presence of Russian tourists in the city space,

\footnotetext{
${ }^{5}$ Survey was conducted in August 2013 in the form of computer-aided telephone interviews on a sample of 1,000 adult Poles (the sample was drawn randomly) and represents population by gender, age, education, town size, and district.
} 
Only as little as $6.4 \%$ of the interviewees asserted that the Russians were not welcomed in the agglomeration, while $12.4 \%$ did not give any opinion regarding the residents of Kaliningrad Oblast in Tri-City. The respondents dissatisfied with Russian presence, referred to dangerous driving, queues in stores, improper attitude towards the locals (according to these interviewees, the Russians were impolite and ill-tempered), as well as road congestion and accidents.

The impact of local border traffic agreement on the functioning of local communities is reflected also in the growth of interest in learning Russian language in Polish parts of the borderland. The attempts to understand the neighbour come as a consequence of efforts to increase the incomes from services provided to the Russians, and should be interpreted as another benefit of introducing visafree traffic on the external frontiers of the EU. Although the motivation for learning neighbour's tongue is often purely economic, it will contribute in the future to better mutual understanding and gradual establishment of contacts. Language barrier constitutes a major problem in border regions, hence overcoming it is crucial for borderland inhabitants' full integration.

Nevertheless, some Russian experts suggest that the LBT regime changed nothing because the consulate of Poland had been issuing annual multi-entry Schengen visas relatively easy. They believe that this regime is not beneficial for the economy of Kaliningrad, especially for consumer market, because the LBT has caused a dramatic increase in 'grey' imports from Poland. Local business feels the increasing competitive pressure from Polish producers and retail trade. Kaliningrad manufacturing companies and retailers claim that federal and regional structure adopt protectionist measures. Expectations of the increasing flow of Polish tourists were not justified. According to M. Więckowski (2010: 109) "For Poles, trips to the countries of the former Soviet Union are decidedly less attractive. Their trips are mainly undertaken for trade purposes". In their eyes, Kaliningrad remains a dangerous and grey city, it is poor, not groomed and interesting, and at the same time too expensive (Kolosov \& Vendina 2014). The LBT didn't yet change these stereotypes. According to the survey conducted in August $2013,73 \%$ of surveyed inhabitants of neighbouring Polish regions have never been to Kaliningrad region. However, those who have recently visited Kaliningrad emphasized its dynamism and positive change. No doubt that negative stereotypes persist partly because by an inadequate promotion and marketing of the region by Russian stakeholders.

Cooperation with Kaliningrad Oblast became an important element of regional and local authorities' polices of both Polish regions. The location of Warmińsko-Mazurskie Voivodeship in the immediate vicinity of Kaliningrad Oblast makes collaboration with the Russians natural. The Voivodeship's strategy for socioeconomic development until 2025 lists such cooperation as an important developmental factor; the document points to the possibility of benefiting from the opportunities offered by local border traffic. The strategy for development of Pomorskie Voivodeship until 2020 stresses the importance of cooperation within the Baltic region, which includes Kaliningrad Oblast.

The significance of cross-border cooperation is also reflected in the activities of counties and municipalities. Particularly notable was the activity of counties of the WarmińskoMazurskie Voivodeship. Out of eleven district authority offices (starostwa) that signed bilateral agreements, nine were located in the Warmia and Mazuria regions. All the frontier counties carry out active cooperation with the Russian side. The farther away from the boundary, the lower the number of self-governments cooperating across the border (Stan demokracji lokalnej... 2012). Additionally, particularly active were the urban counties: Gdańsk, Gdynia, Olsztyn, Elblag (Tab. 3).

It is worth noting that after the introduction of local border traffic regulations, the partnership agreements that had been signed several years before were renewed. In 2012 Elblagg and in 2013 Gdańsk decided 
Table 3. Bilateral agreements of Polish counties included in the local border traffic agreement

\begin{tabular}{|c|c|c|c|c|}
\hline No. & County (powiat) & Partner & $\begin{array}{l}\text { Year of signature } \\
\text { of the agreement }\end{array}$ & $\begin{array}{c}\text { Year of prolongation } \\
\text { of the agreement }\end{array}$ \\
\hline 1 & Gdańsk & Kaliningrad & 1993 & renewed in 2013 \\
\hline 2 & Gdynia & Kaliningrad & 1994 & renewed in 1997 \\
\hline 3 & Olsztyn & Kaliningrad & 1993 & renewed in 1998, 2003, 2008 \\
\hline \multirow[t]{2}{*}{4} & Elblag & Baltiysk & 1994 & \\
\hline & & Kaliningrad & 1994 & renewed in 2012 \\
\hline 5 & Bartoszyce County & Bagrationovsk district & 2001 & - \\
\hline 6 & Giżycko County & Nesterov & 2006 & - \\
\hline 7 & Gołdap County & Gusev district & 2010 & - \\
\hline \multirow[t]{2}{*}{8} & Kętrzyn County & Pravdinsk district & 2004 & - \\
\hline & & Kaliningrad & 2009 & - \\
\hline 9 & Lidzbark County & Bagrationovsk district & 2000 & - \\
\hline 10 & Olecko County & Guryevsk County & 2004 & - \\
\hline \multirow[t]{3}{*}{11} & Węgorzewo County & Chernyakhovsk district & 2003 & - \\
\hline & & Ozyorsk & 2003 & - \\
\hline & & Pravdinsk & 2005 & - \\
\hline
\end{tabular}

Source: Based on diffuse sources

to re-launch cooperation with the city of Kaliningrad to boost the socio-economic benefits. As Gdańsk authorities informed, the agreement was a result of permanent cooperation of the two cities, first established within the town-twinning framework in 1993. Indeed, the contacts became much more dynamic with the opening of local border traffic on the 27th of July 2012 (Biuletyn Informacji Publicznej... 2016).

The significance of the LBT for local and regional economy is also reflected in vigorous efforts of regional self-governments aimed at re-establishing the zone after its shut down in 2016. The marshal of Pomorskie Voivodeship issued letters to the minister for the interior and administration and to the minister of foreign affairs, while the marshal of Warmińsko-Mazurskie Voivodeship sent a letter to the head of Ministry of Foreign Affairs to re-establish LBT on Polish-Russian border.

Also local self-governments have taken actions. Kętrzyn City Council issued a plea to the Ministry of Foreign Affairs to alter the decision concerning the suspension of visa-free traffic.
Additionally meetings and protests with the participation of politicians, local authorities, and residents are organised. Self-governments' efforts enjoy the support of MPs from both the governing coalition (Kukiz'15) and from the opposition (Platforma Obywatelska, .Nowoczesna), who also demand the decision to be changed. The government, however, justifies shutting down the LBT with security reasons and as the article was being published, it has not changed its position.

\section{Conclusion}

Polish-Russian borderland is an intriguing research area not only due to its high sensitivity to historical, social, and economic factors, but also because of its geopolitical nature. On the one hand, the Polish-Russian border is considered a local boundary, as it is crossed primarily by the inhabitants of the borderland, on the other hand - it reflects the bilateral Polish-Russian relations and EU policies towards its neighbouring countries.

In their traditional understanding the LBT zones had mainly humanitarian and 
compensating purposes. Their aim was not to create cross-border regions, but to facilitate crossings of the boundary for societies divided by state boundaries. Hence the regulations that establish the range limit of $30 / 50 \mathrm{~km}$ are usually an obstacle in realisation of zones' actual function, i.e. integrating, and not merely compensating the nuisances stemming from the partitions. The success of the four-year period of the LBT zone's functioning on the Polish-Kaliningrad border came as a result of modification of those regulations and the inclusion of economic regions otherwise heavily affected in the functional dimension. The example of the Polish-Russian borderland, where the visa-free traffic zone was significantly extended, corroborates the importance of including large urban centres, academic cities, and areas that attract tourism. The concessions made by the EU in this case were justified as an attempt to prevent artificial division of Kaliningrad region (Second report on the implementation and functioning of the local border traffic regime, 2011). Nonetheless, the benefits from extending the zone have far exceeded the adopted assumptions and have substantially contributed to cross-border integration. Having this experience in mind, it should be noted that to exploit the integration opportunities of LBT, its range needs to be adjusted individually to each area, with special attention dedicated to adapting it to existing settlement pattern, and in particular to the presence of highertier urban centres.

The residents of areas covered by the LBT used the benefit of location for building an interdependent borderland. The intensity of traffic and the nature of cross-border contacts allow to state that during the four years of functioning of the zone, socially created cross-border soft space was indeed formed.

Emergence of such areas is extremely important in building cooperation and goodneighbourly relations, not only in a post-conflict political situation, but also for amelioration of conflicts. What often becomes a barrier in building cross-border spaces of cooperation is the parish politics of interests framed within the context of the administrative boundaries of the counties (cf. Walsh 2015). However, this was not the case while building a common area of cooperation between Kaliningrad Oblast and the Warmińsko-Mazurskie and Pomorskie Voivodeships. On the contrary the commitment and the role of the regional authorities in the processes of the LBT zone creation and its functioning exemplified the efficiency of united grass-roots efforts. Thus, the region had the chance to become a model of national and local policies' cooperation in border areas. The decision of Polish authorities to shut down the LBT has verified these expectations. It has proved yet again that socio-economic initiatives in border regions are deterministically dependent on the decisions of central governments. The fact that the interviewees of the survey pointed most frequently to the unpredictability of the decisions of Russian central government, whose policies dynamically change, as the main obstacle in the development of the LBT, perfectly illustrates how unstable and difficult to predict in long term are the circumstances in which such initiatives operate - even those as successful as the LBT. None of the respondents considered a possibility that the Polish authorities could definitively change their stance.

The case of success of an otherwise failed experiment of LBT on the Polish-Kaliningrad Oblast border offers analytically interesting material for describing processes of peripheralisation of areas. As the analysis of 'life' and 'death' of the local border traffic zone indicates, the peripheralisation of areas does not necessarily stem from their endogenous characteristics. Exterior factors may play a key role, not only limiting the endogenously generated potential but actually, in a longer perspective, causing its demise. Lack of confidence in the stability of prevailing regulations is the fundamental obstacle that prevents the development of regional socio-economic activities. Restoring lost confidence is a lengthy process, while the residents' and entrepreneurs' inactivity - a consequence of losing trust - contributes, in turn, to region's peripheralisation. 
In the context of complicated relations between Russia and the EU, and Poland in particular, it is difficult to overestimate the positive role that the LBT played in amelioration of conflicts. The borderland with the LBT could potentially become a 'model region of crossborder cooperation' or a 'laboratory of social changes' between Russia and the EU countries; an objective proposed by some experts in the early 2000s could have had a chance to be implemented. Unfortunately, yet this time, it did not happen so.

\section{References}

Allmendinger P., Haughton G., Knieling J., Othengrafen F., 2015. Soft spaces in Europe: Re-negotiating governance, boundaries and borders. London: Routledge.

Anisiewicz R., Palmowski T., 2014. Small border traffic and cross-border tourism between Poland and the Kaliningrad Oblast of the Russian Federation. Quaestiones Geographicae, vol. 33, no. 2, pp. 79-86.

Attitude of Kaliningraders to Poles, 2014. Otnoshenie kaliningradtsev $k$ poliakam i naoborot. http://polsha24.com/novosti/otnoshenie-kaliningradtsev-k-poliakam-i-naoborot-5412/ [10 June 2016].

BDL, 2016. Bank Danych Lokalnych, stat.gov.pl/bdl/ [15 November 2016].

Biuletyn Informacul Publicznej Miasta Gdańsk, 2016. http://bip.gdansk.pl/rada-miasta/Gdansk-Kaliningrad,a,27655 [10 October 2016].

Doliwa-Klepacka A., 2011. Możliwości odstapienia od reżimu wizowego przy przekraczaniu zewnętrznej granicy Unii Europejskiej [in:] M. Zdanowicz (ed.), Przyjazna granica niezbędnym elementem wzmacniania stosunków społeczeństw Polski i Rosji, Białystok: Białostockie Studia Prawnicze, pp. 142-157.

Domaniewski S., StudzIŃSKA D., 2016. The small border traffic zone between Poland and Kaliningrad Region (Russia): The impact of a local visafree border regime. Geopolitics, vol. 21, no. 3, pp. 538-555.

\section{Acknowledgements}

Vladimir Kolosov, Maria Zotova and Alexander Sebentsov thank Russian Science Foundation for supporting the project "Russian Borders: Challenges of Neighbourhood" (grant No. 14-18-03621) which allowed them conducting the Russian part of the study.

Editors' note:

Unless otherwise stated, the sources of tables and figures are the authors', on the basis of their own research.

DudZIŃSKA K., Dyner A., 2013. Mały ruch graniczny między obwodem kaliningradzkim a Polska - wyzwania, szanse i zagrożenia. Policy Paper, no. 29 (77), Warszawa: PISM.

EBERHARDT P., 2012. The Curzon line as the eastern boundary of Poland: The origins and the political background. Geographia Polonica, vol. 85, no. 1, pp.5-21.

Fedorov G.M., Zverev Ju.M., Korneevec V.S., 2013. Rossija na Baltike: 1990-2012. Kaliningrad: Izd-vo BFU im. I. Kanta.

Fedorov G., 2010. The Kaliningrad dilemma: A 'development corridor' or a 'double periphery'? The geopolitical factor of the development of the Russian exclave on the Baltic Sea. Baltic Region, no. 2, pp. 4-12.

Fomina J., 2012. Umowa o małym ruchu granicznym z obwodem kaliningradzkim: Sukces polskiej prezydencji oraz budowanie zaufania między Polska a Rosja. Warszawa: Analiza Fundacji Batorego, http://www.batory.org.pl/upload/files/ Programy\%20operacyjne/Otwarta\%20Europa/ Kaliningrad_pol.pdf. [20 March 2017]

Jaroszewicz M., 2012. Niemożliwe uczynić możliwym. Perspektywy ruchu bezwizowego pomiędzy UE a wschodnimi partnerami. Warszawa: Ośrodek Studiów Wschodnich im. Marka Karpia.

KAmińSKI K., 2013. Mały ruch graniczny - pół roku od wejścia w życie umowy. Nowa Europa Wschodnia. http://www.new.org.pl/2UI3-03-03,maly_ruch_graniczny.html. [1 July 2015].

Kolosov V., Vendina O., 2014. The youth in Kaliningrad, Gdansk and Klaipeda: Geopolitical vision 
of the world, identity and images of the other. Baltic Region, no. 4(22), pp. 4-26.

KomORNICKI T., 1999. Granice Polski. Analiza zmian przenikalności w latach 1990-1996. Geopolitical Studies, vol. 5, Warszawa: Instytut Geografii i Przestrzennego Zagospodarowania PAN.

KOMORNICKI T., 2010. Flows of persons and goods across the Polish segment of the outer boundary of the European Union - results of a research project. Europa XXI, vol. 20, pp. 9-29.

LITHUANIA HAS FROZEN TALKS ON BORDER MOVEMENT OF THE KaLININGRAD REGION, 2014. Litva zamorozila peregovory o malom prigraničnom peredviženii s Kaliningradskoj oblast'ju. http://www.rosbalt. ru/kaliningrad/2014/06/09/1278562.html [26 October 2016].

LITHUANIAN FOREIGN MINISTER: POLAND PROPOSALS DO NOT MEet THE REQUIREMENTS OF tHe SChengen, 2010. MID Litvy: predloženija Pol'ši ne sootvetstvujut trebovanijam Šengena. http://www. newkaliningrad.ru/news/politics/k1119062.html [26 October 2013].

Martinez O.J., 1994. The dynamics of border interaction: New approaches to border analysis [in:] C.H. Schofield (ed.), Global boundaries, world boundaries, World boundaries series, vol. 1, London: Routledge, pp. 1-15.

MeLNIK A., 2006. Institutional aspects of Ukraine and Poland 's transborder cooperation: Results and problems [in:] J. Kitowski (ed.), Regional transborder cooperation in countries of Central and Eastern Europe - a balance of achievements. Geopolitical Studies, vol. 14, Warsaw: Institute of Geography and Spatial Organization PAS, University of Rzeszów, pp. 117-137.

MoraczewsKA A., 2008. Transformacja funkcji granic Polski. Lublin: Wydawnictwo Uniwersytetu Marii Curie-Sklodowskiej.

Palmowski T., 2010. Problems of cross-border cooperation between Poland and the Kaliningrad Oblast of the Russian Federation. Questiones Geographicae, vol. 29, no. 4, pp. 75-82.

PALMOWSKI T., 2013. Kaliningrad - szansa czy zagrożenie dla Europy Bałtyckiej? Gdańsk-Pelplin: Wydawnictwo Bernardinum.

POLSKA WCIAŻ MAŁO OPtACALNA DLA ROSJAN, 2015. Puls Biznesu. http://www.pb.pl/4189873,87058,polska-wciaz-malo-oplacalna-dla-rosjan [15 October 2016].
Regulation (EC) No 1931/2006 of the European Parliament and of the Council of 20 December 2006 laying down rules on local border traffic at the external land borders of the Member States and amending the provisions of the Schengen Convention

REPORT, 2015. Rossijsko-pol'skie otnošenija: Sociologičeskij monitoring 2012-2014. http://wciom.ru/fileadmin/file/reports_ conferences/2015/2015-03-06-roosia-polsha. pdf [10 June 2016].

RožKOV-JUR'EVSKIJ Ju., 2014. Some aspects of historical and political geography of the Kaliningrad region. Pskovskii Regionologičeskii Žurnal, no.18, pp. 104-121.

RuCH GRANICZNy, 2011-2015. Ruch graniczny oraz przepływ towarów i usług na zewnętrznej granicy unii europejskiej na terenie Polski w 2010-2014 roku. Warszawa-Rzeszów: Central Statistical Office.

Russia after the embargo, 2015. Čelnoki i vlast': čto stalo s prigraničnymi rajonami Rossii posle èmbargo Podrobnee na RBK. http://www.rbc.ru/ opinions/economics/21/04/2015/5535d11d9a 7947852c7187b7 [10 November 2016].

RUSSIAN FOOD, 2015. Kupujemy więcej rosyjskiej żywności. http://www.farmer.pl/fakty/polska-swiat/ kupujemy-wiecej-rosyjskiej-zywnosci,56425.html [10 November 2016].

Russian-Polish Relations, 2015. Rossijskopol'skie otnošenija skladyvajutsja ploho. http://www.polska-kaliningrad.ru/home/ 10-newsfrompoland/5461-rossijsko-polskieotnosheniya-skladyvayutsya-plokho-otsenivayutrossijskie-smi [15 October 2016].

RUSSIAN WEST, 2014. Za polgoda kaliningradcy potratili v Pol'še $92 \mathrm{~m} / \mathrm{n}$. zlotyh. http://ruwest. ru/news/24512/ [30 August 2014].

Sebentsov A.B., Zotova M.V., 2013. Geography and economy of the Kaliningrad region: Limitation and prospects of development. Baltic Region, no. 4(18), pp. 81-94.

SPRAWOZDANIE MRG, 2014. Wdrażanie i funkcjonowanie rozporządzenia Parlamentu Europejskiego i Rady (UE) nr 1342/2011 zmieniajace rozporzadzenie (WE) nr 1931/2006 w sprawie włączenia obwodu kaliningradzkiego i niektórych polskich okręgów administracyjnych do obszaru uznawanego za strefę przygraniczna oraz dotyczące dwustronnej umowy zawartej w zwiqzku 
z ta zmiana między Polską a Federacją Rosyjskq, Bruksela: Komisja Europejska.

Sprawozdanie UE, 2011. Drugie sprawozdanie z wdrażania i funkcjonowania przepisów dotyczacych małego ruchu granicznego wprowadzonych rozporzadzeniem. Nr 1931/2006, Bruksela: Komunikat Komisji do Parlamentu Europejskiego i Rady.

Stan demokracil lokalnej na pograniczu PolSKO-ROSYJSKIM I JEGO IMPLIKACJE DLA WSPÓŁPRACY TRANSGRANICZNEJ, 2012. Sprawozdanie z projektu badawczego, Olsztyn: Uniwersytet Warmińsko-Mazurski.

StRATEGIA ROZWOJU SPOŁECZNO-GOSPODARCZEGO WOJEWÓDZTWA POMORSKIEGO DO ROKU 2020, 2012. Gdańsk: Urząd Marszałkowski Województwa Pomorskiego.

StRATEGIA ROZWOJU SPOŁECZNO-GOSPODARCZEGO WOJEWÓDZTWA WARMIŃSKO-MAZURSKIEGO DO ROKU 2025, 2013. Olsztyn: Urząd Marszałkowski Województwa Warmińsko-Mazurskiego.

TANAKA H., 2006. Carpathian Euroregion and crossborder governance. The Journal of Comparative Economic Studies, vol. 2, pp. 59-80.

THE LOWEST FOOD PRICES, 2015. V Pol'še samye nizkie ceny na produkty pitanija na vsej territorii
ES. http://www.polska-kaliningrad.ru/home/ 10-newsfrompoland/5446-v-polshe-samye-nizkie-tseny-na-produkty-pitaniya-na-vsej-territoriievropejskogo-soyuza [10 November 2016].

Umowa mięzZY RZĄDem Rzeczypospolitej Polskiej a RZĄDEM FederaCul RosysSKIeJ O ZASADACH MALEGO RUCHU GRANICZNEGO, podpisana w Moskwie dnia 14 grudnia 2011 r., Dz.U. 2012, poz. 814.

VISA PRIVILIGES. 2010. http://kgd.ru/news/society/ item/5940-polsha-vystupaet-za-vizovye-Igotyzhitelyam-kaliningradskoj-oblasti [10 June 2016].

WALSH C., 2015. Creating a space for cooperation: Soft spaces, spatial planning and territorial cooperation on the island of Ireland [in:] P. Allmendinger, G. Haughton, J. Knieling, F. Othengrafen (eds.), Soft spaces in Europe: Re-negotiating governance, boundaries and borders, London: Routledge, pp. 192-212.

Wenerski Ł., KaźmierkieWicz P., 2013. Krajobraz pogranicza. Perspektywy i doświadczenia funkcjonowania małego ruchu granicznego z Obwodem Kaliningradzkim. Warszawa: Instytut Spraw Publicznych.

WIĘCKOWSKI M., 2010. Specific features of development of tourism within the areas neighbouring upon the Polish eastern border. Europa XXI, 20, pp. 101-115.
(C) Iwona Sagan - Vladimir Kolosov - Dominika Studzińska • Maria Zotova • Alexander Sebentsov • Klaudia Nowicka (C) Geographia Polonica

(C) Institute of Geography and Spatial Organization

Polish Academy of Sciences • Warsaw • 2018
Article first received $•$ December 2016 Article accepted • April 2017 